\title{
Evidence for a novel class of microbial 3-deoxy- D-arabino-heptulosonate-7-phosphate synthase in Streptomyces coelicolor A3(2), Streptomyces rimosus and Neurospora crassa
}

\author{
Graeme E. Walker, ${ }^{1}$ Bryan Dunbar, ${ }^{3}$ lain S. Hunter, ${ }^{2}$ Hugh G. Nimmo' \\ and John R. Coggins ${ }^{1}$
}

Author for correspondence: John R. Coggins. Tel: +44 141330 5267. Fax: +44 1413304620.

e-mail: J.Coggins@bio.gla.ac.uk

1 Division of Biochemistry and Molecular Biology, University of Glasgow, Glasgow G12 8QQ, UK

2 Department of Bioscience and Biotechnology, University of Strathclyde, Glasgow G1 1QW, UK

3 Department of Molecular and Cell Biology,

University of Aberdeen, Aberdeen AB9 1AS, UK

\begin{abstract}
The tryptophan-sensitive 3-deoxy-D-arabino-heptulosonate-7-phosphate (DAHP) synthases from Streptomyces coelicolor A3(2), Streptomyces rimosus and Neurospora crassa have been purified to homogeneity. All three enzymes have a subunit $M_{r}$ of $\mathbf{5 4 0 0 0}$. The $S$. coelicolor DAHP synthase was physically and kinetically characterized and the $\mathbf{N}$-terminal amino acid sequence was obtained. The $\mathbf{N}$-terminal amino acid sequence could not be obtained for the enzymes from $\mathbf{S}$. rimosus and $\boldsymbol{N}$. crassa, their $\mathbf{N}$-termini apparently being blocked. However, following proteolytic digestion, internal amino acid sequences were obtained from both enzymes. A comparison with the known DAHP synthase sequences indicated that these DAHP synthases are unrelated to other microbial DAHP synthase sequences but are similar to plant DAHP synthases. Up until now, two distinct classes of DAHP synthase have been described, one comprising exclusively enzymes from plants, the other restricted to enzymes from micro-organisms. These studies indicate that the class containing the plant DAHP synthases also contains enzymes from a microbial eukaryote and from several bacteria.
\end{abstract}

Keywords: 3-deoxy-D-arabino-heptulosonate-7-phosphate synthase, shikimate pathway, Streptomyces species, Neurospora crassa

\section{INTRODUCTION}

In micro-organisms and plants, chorismate is the common metabolic precursor of the aromatic amino acids, vitamins $\mathrm{E}$ and $\mathrm{K}$, folic acid, ubiquinone, plastoquinone, enterochelin and various secondary metabolites. This compound is synthesized by way of the seven-step shikimate pathway (Haslam, 1974, 1993; Weiss \& Edwards, 1980). Other organisms lack this biosynthetic ability and require a supplementary dietary intake of aromatic amino acids.

The first step in the shikimate pathway involves the condensation of phosphoenolpyruvate (PEP) and erythrose 4-phosphate (E4P) to form the phosphorylated 7 carbon keto sugar acid, 3-deoxy-D-arabino-heptulosonate-

Abbreviations: DAHP, 3-deoxy-D-arabino-heptulosonate 7-phosphate; E4P, erythrose 4-phosphate; PEP, phosphoenolpyruvate.

The PIR accession numbers for the Streptomyces coelicolor, Streptomyces rimosus and Neurospora crassa partial protein sequences reported in this paper are P80574, P80575 and P80576, respectively. 7-phosphate (DAHP) and inorganic phosphate. This is achieved by the action of DAHP synthase (EC 4.1.2.15) (Srinivasan \& Sprinson, 1959).

Branched, purely biosynthetic pathways exhibit a diversity of control mechanisms in different species. In the biosynthetic pathway for aromatic amino acids, different control and organization of the constituent enzymes are well-documented (Herrmann, 1983; Bentley, 1990). Carbon flow through the shikimate pathway is controlled at the first step by modulation of DAHP synthase activity either by feedback inhibition or by transcriptional regulation. Diverse patterns of control have been described for DAHP synthases from different organisms (Bentley, 1990). Different micro-organisms possess from one to three isoenzymes which are inhibited by feedback control, by end-products or intermediates of the pathway, or a combination of the two. In exceptional cases, the enzymes may be unregulated.

Nucleotide sequences for microbial DAHP synthases have been obtained for the three Escherichia coli isoenzymes 
(Davies \& Davidson, 1982; Schultz et al., 1984; Ray et al., 1988), the two Saccharomyces cerevisiae isoenzymes (Paravicini et al., 1988; Kunzler et al., 1992), Candida albicans (Pereira \& Livi, 1993), Salmonella typhimurium (Muday \& Herrmann, 1990), Corynebacterium glutamicum (Chen et al., 1993) and for part of the gene from Erwinia berbicola (Xia et al., 1993). They exhibit a striking level of sequence similarity, suggesting that they are derived from a common ancestral sequence.

cDNA clones encoding DAHP synthases have been isolated from potato (Dyer et al., 1990; Zhao \& Herrmann, 1992), tobacco (Wang et al., 1991), Arabidopsis thaliana (Keith et al., 1991) and tomato (Gorlach et al., 1993). By varying assay conditions, two distinct plant isoforms possessing discrete divalent metal cation requirements can be identified (for review, see Mousdale \& Coggins, 1993). All the plant sequences display a high degree of similarity (Keith et al., 1991; Gorlach et al., 1993) and are unrelated to the microbial sequences (Dyer et al., 1990).

The genus Streptomyces comprises a group of Grampositive obligately aerobic bacteria characterized by their morphological and metabolic capabilities (for review, see Chater \& Hopwood, 1993). The antibiotics produced by streptomycetes are of considerable interest because of their medical, veterinary and agricultural importance (Demain, 1983).

The shikimate pathway enzymes, and DAHP synthase in particular, have not been extensively studied in Streptomyces, and no amino acid sequence data have been obtained for any Streptomyces DAHP synthase. An understanding of the regulation of the pathway would be of interest in determining factors influencing provision of precursors for antibiotic biosynthesis, given that many antibiotic structures are derived, in part, from the shikimate pathway. With this objective, a study on the DAHP synthases from two species of Streptomyces was undertaken.

In this paper, we report the purification and characterization of a single tryptophan-sensitive DAHP synthase activity from Streptomyces coelicolor A3(2) and the determination of its $\mathrm{N}$-terminal amino acid sequence. In addition, internal amino acid sequences have been obtained for DAHP synthases of Streptomyces rimosus and Neurospora crassa. A comparison with the published DAHP synthase sequences indicates that the Streptomyces and Neurospora DAHP synthases are unrelated to other microbial DAHP synthase sequences but are similar to plant DAHP synthases.

\section{METHODS}

Strains and growth of cells. S. coelicolor A3(2) JI3456 (SCP1 ${ }^{\mathrm{NF}}$, $\mathrm{SCP}^{-}$) was provided by Professor D. A. Hopwood, John Innes Institute, Norwich, UK. Cells were grown on a minimal medium comprising inorganic salts supplemented with $0.4 \%(\mathrm{w} / \mathrm{v})$ glucose as described by Bramwell et al. (1993).

S. rimosus strain 4018 was provided by Pfizer (Sandwich, UK) and was grown as described by Stuart \& Hunter (1993).
Freeze-dried N. crassa mycelia (strain 74-OR23-1A, FGSC 987; Fungal Genetics Stock Center, Humboldt State University Foundation, Arcata, CA, USA) were obtained as described by Lumsden \& Coggins (1977).

Assay of DAHP synthase activity. DAHP synthase activity was measured using either a coupled continuous or a direct continuous spectrophotometric assay (Mousdale \& Coggins, 1993). Assays were performed at $30^{\circ} \mathrm{C}$ in a total volume of $1 \mathrm{ml}$. For the coupled assay, activity was measured by using the second to fourth enzymes of the shikimate pathway to couple the formation of DAHP to the oxidation of NADPH. The assay cocktail contained $50 \mathrm{mM}$ bis-tris propane/ $\mathrm{HCl}$ buffer $(\mathrm{pH} 7 \cdot 0)$, $0.5 \mathrm{mM}$ PEP, $1.0 \mathrm{mM}$ E4P, $0.1 \mathrm{mM}$ NADPH, $10 \mu \mathrm{M} \mathrm{NAD}^{+}$, $0 \cdot 1$ units of $E$. coli dehydroquinate synthase, 0.05 units of $E$. coli dehydroquinase and 0.05 units of $E$. coli shikimate dehydrogenase. The oxidation of NADPH was monitored at $340 \mathrm{~nm}$ $\left(\varepsilon_{340}=6.18 \times 10^{3} \mathrm{M}^{-1} \mathrm{~cm}^{-1}\right)$ using a Philips PU8720 spectrophotometer. The coupling enzymes dehydroquinate synthase, 3-dehydroquinase and shikimate dehydrogenase were purified from overproducing E. coli strains as described by Medhi et al. (1987), Chaudhuri et al. (1987b) and Chaudhuri et al. (1987a), respectively. For the direct assay (Schoner \& Herrmann, 1976), the standard assay mixture contained $50 \mathrm{mM}$ bis-tris propane/ $\mathrm{HCl}$ buffer $(\mathrm{pH} 7 \cdot 0), 0.5 \mathrm{mM}$ PEP and $1.0 \mathrm{mM}$ E4P. (One unit of enzyme activity is defined as the amount catalysing the conversion of $1 \mu \mathrm{mol}$ substrate to product $\mathrm{min}^{-1}$.)

Protein estimation. Protein was determined by the method of Bradford (1976), with bovine serum albumin as standard.

\section{Small-scale purification of S. coelicolor A3(2) DAHP synthase}

Unless otherwise stated, all manipulations following cell breakage were performed at $4{ }^{\circ} \mathrm{C}$.

Step 1: extraction and centrifugation. A $70 \mathrm{~g}$ batch (wet weight) of $S$. coelicolor cells was suspended in $20 \mathrm{ml} 100 \mathrm{mM}$ potassium phosphate buffer ( $\mathrm{pH} 7 \cdot 0$ ), containing $1.2 \mathrm{mM}$ PMSF, $3.5 \mathrm{mM}$ benzamidine and $0.4 \mathrm{mM} \mathrm{D}^{\prime} \mathrm{T}^{\top} \mathrm{T}$ (buffer $\mathrm{A}$ ) and broken by two passages through a French pressure cell. This material was then centrifuged at $100000 \mathrm{~g}$ for $1 \mathrm{~h}$. DAHP synthase was purified from the resulting cell-free extract.

Step 2: salt fractionation with $\left(\mathrm{NH}_{4}\right)_{2} \mathrm{SO}_{4}$. The crude extract was diluted to give a protein concentration of $10 \mathrm{mg} \mathrm{m}^{-1}$ and solid $\left(\mathrm{NH}_{4}\right)_{2} \mathrm{SO}_{4}$ was added to give $35 \%$ saturation $\left(209 \mathrm{~g} \mathrm{l}^{-1}\right)$. The mixture was stirred for $20 \mathrm{~min}$ and the precipitated proteins were removed by centrifugation at $28000 \mathrm{~g}$ for $20 \mathrm{~min}$. The supernatant was adjusted to $65 \%$ saturation with solid $\left(\mathrm{NH}_{4}\right)_{2} \mathrm{SO}_{4}\left(199 \mathrm{~g} \mathrm{l}^{-1}\right)$ and stirred for $20 \mathrm{~min}$. The precipitated protein was collected by centrifugation at $28000 \mathrm{~g}$ for $20 \mathrm{~min}$, resuspended in $15 \mathrm{ml} 50 \mathrm{mM}$ potassium phosphate buffer (pH 7.0), $1.2 \mathrm{mM}$ PMSF, $3.5 \mathrm{mM}$ benzamidine and $0.4 \mathrm{mM}$ DTT (buffer B) and dialysed overnight against 21 buffer B.

Step 3: anion-exchange chromatography on Mono Q. Steps 3, 4 and 5 were carried out at room temperature using a Pharmacia FPLC system. The dialysed material was loaded onto a preparative Mono $Q$ anion-exchange column (volume $8 \mathrm{ml}$ ) equilibrated in buffer $\mathrm{B}$. The column was washed with buffer until the $A_{280}$ of the eluate had returned to the baseline value. Protein was eluted from the column with an $80 \mathrm{ml}$ gradient of $0-0.5 \mathrm{M} \mathrm{Na}_{2} \mathrm{SO}_{4}$ in buffer $\mathrm{B}$, flow rate $4 \mathrm{ml} \mathrm{min}^{-1}$. Fractions $(2 \mathrm{ml})$ were collected and assayed for DAHP synthase, and those containing the highest activity were retained.

Step 4: hydrophobic-interaction chromatography on phenylSuperose. Retained fractions were made to $1 \mathrm{M}\left(\mathrm{NH}_{4}\right)_{2} \mathrm{SO}_{4}$ by the addition of solid $\left(\mathrm{NH}_{4}\right)_{2} \mathrm{SO}_{4}$ and applied to a phenylSuperose hydrophobic-interaction column (volume $1 \mathrm{ml}$ ) equil- 
ibrated in $50 \mathrm{mM}$ potassium phosphate buffer $(\mathrm{pH} 7 \cdot 0), 1 \cdot 2 \mathrm{mM}$ PMSF, $3.5 \mathrm{mM}$ benzamidine, $0.4 \mathrm{mM}$ DTT and $0.9 \mathrm{M}$ $\left(\mathrm{NH}_{4}\right)_{2} \mathrm{SO}_{4}$ (buffer $\mathrm{C}$ ). After the $A_{280}$ value of the eluate had returned to the pre-loading value, a $0.9-0 \mathrm{M}\left(\mathrm{NH}_{4}\right)_{2} \mathrm{SO}_{4}$ gradient was run in a volume of $15 \mathrm{ml}$. The column was washed at $0.5 \mathrm{ml} \mathrm{min}-1$ and $0.5 \mathrm{ml}$ fractions were collected. After assaying for DAHP synthase activity, appropriate fractions were retained. These fractions were desalted into $215 \mathrm{mM}$ sodium phosphate buffer, $\mathrm{pH} 6 \cdot 7$, containing $0.4 \mathrm{mM}$ DTT (buffer D) using a Pharmacia FPLC desalting column (G-50).

Step 5: anion-exchange chromatography on Mono Q. The partially purified material was loaded onto an analytical Mono $Q$ anionexchange column (volume $1 \mathrm{ml}$ ) equilibrated in buffer $D$. Following washing with buffer D, protein was eluted with a $30 \mathrm{ml}$ linear gradient of $215-320 \mathrm{mM}$ sodium phosphate. The flow rate was $1 \mathrm{ml} \mathrm{min}^{-1}$ and $0.5 \mathrm{ml}$ fractions were collected. Fractions containing the peak of DAHP synthase activity were pooled and retained.

Large-scale purification of S. coelicolor A3(2) DAHP synthase. Step 1 (extraction and centrifugation) was carried out as described for the small-scale purification of $S$. coelicolor DAHP synthase, except that $0 \cdot 2 \mathrm{mM}$ PEP was included in the extraction buffer and a $200 \mathrm{~g}$ batch of cells was used. Step 2 [salt fractionation with $\left(\mathrm{NH}_{4}\right)_{2} \mathrm{SO}_{4}$ ], step 3 (hydrophobic-interaction chromatography on phenyl-Sepharose) and step 4 (anionexchange chromatography on Mono Q) were carried out as described for the purification of the $S$. rimosus DAHP synthase (below). All buffers were supplemented with $0 \cdot 2 \mathrm{mM}$ PEP, $1.2 \mathrm{mM}$ PMSF and $3.5 \mathrm{mM}$ benzamidine.

\section{Purification of S. rimosus DAHP synthase}

Unless otherwise stated, all manipulations following cell breakage were performed at $4{ }^{\circ} \mathrm{C}$.

Step 1: extraction and centrifugation. An $85 \mathrm{~g}$ batch (wet weight) of $S$. rimosus cells was suspended in $60 \mathrm{ml} 100 \mathrm{mM}$ bis-tris propane buffer $(\mathrm{pH} 7.0)$, containing $3.5 \mathrm{mM}$ benzamidine,

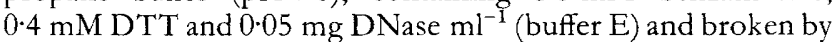
two passages through a French pressure cell. The extract was then stirred on ice for $60 \mathrm{~min}$ to allow for digestion of genomic DNA. This material was then centrifuged at $100000 \mathrm{~g}$ for $1 \mathrm{~h}$. DAHP synthase was purified from the resulting cell-free extract.

Step 2: salt fractionation with $\left(\mathrm{NH}_{4}\right)_{2} \mathrm{SO}_{4}$. This was carried out as above for the small-scale purification of $S$. colicolor DAHP synthase. In this instance, crude extract was diluted in buffer $\mathrm{E}$ and the precipitated protein was resuspended in $25 \mathrm{ml} 25 \mathrm{mM}$ bis-tris propane buffer ( $\mathrm{pH} 7.5$ ), containing $0.4 \mathrm{mM} \mathrm{DTT}$ (buffer F) and dialysed overnight against $2 \times 21$ buffer $F$.

Step 3: anion-exchange chromatography on DEAE-Sephacel. This dialysate was centrifuged at $100000 \mathrm{~g}$ for $20 \mathrm{~min}$ to remove precipitated protein and other debris, prior to application onto a DEAE-Sephacel anion-exchange column (volume $70 \mathrm{ml}$ ) equilibrated in buffer $F$. The column was washed with buffer $F$ until the $A_{280}$ of the eluate was less than $0 \cdot 3$. The column was then washed with buffer $\mathrm{F}$ containing $150 \mathrm{mM} \mathrm{NaCl}$ until the $A_{280}$ of the eluate was again less than 0.3 . Protein was then eluted with a gradient of $150-350 \mathrm{mM} \mathrm{NaCl}$ in 11 buffer $\mathrm{F}(15$ column volumes) and fractions $(16 \mathrm{ml})$ were collected and assayed as before.

Step 4: hydrophobic-interaction chromatography on phenylSepharose. The pooled fractions from step 3 were made to $0 \cdot 8 \mathrm{M}$ $\left(\mathrm{NH}_{4}\right)_{2} \mathrm{SO}_{4}$ and loaded onto a phenyl-Sepharose hydrophobicinteraction column (bed volume $10 \mathrm{ml}$ ) equilibrated in $50 \mathrm{mM}$ bis-tris propane/ $\mathrm{HCl}(\mathrm{pH} 7.5), 0.7 \mathrm{M}\left(\mathrm{NH}_{4}\right)_{2} \mathrm{SO}_{4}$ and $0.4 \mathrm{mM}$ DTT (buffer $G$ ). The column was washed with buffer $G$ until the $A_{280}$ of the eluate was less than $0 \cdot 1$. Protein was eluted from the column with a $150 \mathrm{ml}$ gradient of $0 \cdot 7-0 \mathrm{M}\left(\mathrm{NH}_{4}\right)_{2} \mathrm{SO}_{4}$ in $50 \mathrm{mM}$ bis-tris propane buffer (pH 7.5), containing $0.4 \mathrm{mM}$ DTT, collecting $3 \mathrm{ml}$ fractions. These were assayed for DAHP synthase activity and those containing the highest activity were retained and dialysed against $1125 \mathrm{mM}$ bis-tris propane $/ \mathrm{HCl}$ (pH 7.5), $50 \mathrm{mM} \mathrm{NaCl}$ and $0.4 \mathrm{mM} \mathrm{DTT}$ (buffer $\mathrm{H}$ ).

Step 5: anion-exchange chromatography on Mono Q. Steps 5 and 6 were carried out at room temperature using a Pharmacia FPLC system. The dialysate was applied to an analytical Mono $Q$ anion-exchange column (volume $1 \mathrm{ml}$ ) equilibrated in buffer $\mathrm{H}$. Following washing with buffer $\mathrm{H}$, protein was eluted with a gradient of $150-300 \mathrm{mM} \mathrm{NaCl}$ in $20 \mathrm{ml}$ buffer $\mathrm{H}$. Fractions $(0.5 \mathrm{ml})$ were collected and assayed as before.

Step 6: hydrophobic-interaction chromatography on phenylSuperose. Retained fractions were made to $1 \cdot 1 \mathrm{M}\left(\mathrm{NH}_{4}\right)_{2} \mathrm{SO}_{4}$ by the addition of solid $\left(\mathrm{NH}_{4}\right)_{2} \mathrm{SO}_{4}$ and applied to a phenylSuperose hydrophobic-interaction column (volume $1 \mathrm{ml}$ ) equilibrated in $50 \mathrm{mM}$ bis-tris propane/ $\mathrm{HCl}(\mathrm{pH} 7.5), 0.4 \mathrm{mM}$ DTT and $1.1 \mathrm{M}\left(\mathrm{NH}_{4}\right)_{2} \mathrm{SO}_{4}$ (buffer I). After the $A_{280}$ value of the eluate had returned to the pre-loading value a $1.1-0 \mathrm{M}$ $\left(\mathrm{NH}_{4}\right)_{2} \mathrm{SO}_{4}$ gradient was run in a volume of $15 \mathrm{ml}$ and $0.5 \mathrm{ml}$ fractions were collected. After assaying for DAHP synthase activity, appropriate fractions were retained and stored.

Purification of $\boldsymbol{N}$. crassa tryptophan-sensitive DAHP synthase. The enzyme was purified essentially as described by Nimmo \& Coggins (1981a), except that at the initial stage a DEAEcellulose (DE52) chromatography step was employed to remove contaminating proteases (Coggins et al., 1987).

PAGE. Electrophoresis in the presence of SDS was performed by the method of Laemmli (1970), with a $3 \%(\mathrm{w} / \mathrm{v})$ stacking gel and a $10 \%(\mathrm{w} / \mathrm{v})$ running gel. After electrophoresis, gels were stained for protein using either Coomassie Brilliant Blue dye or the silver nitrate method (Wray et al., 1981).

Determination of native $\boldsymbol{M}_{\mathbf{r}}$. Gel-permeation chromatography on a Superose 12 column was used to estimate the native $M_{r}$ of the purified $S$. coelicolor enzyme. The column buffer was $50 \mathrm{mM}$ potassium phosphate, $\mathrm{pH} 7 \cdot 0,0.4 \mathrm{mM}$ DTT (flow rate $=0.3 \mathrm{ml} \mathrm{min}^{-1}$, fraction size $0.3 \mathrm{ml}$ ). Protein was monitored at $280 \mathrm{~nm}$. The column was calibrated with the following standard proteins: pig heart malate dehydrogenase $\left(M_{\mathrm{r}} 70000\right)$, pig muscle lactate dehydrogenase $\left(M_{\mathrm{r}} 140000\right)$, rabbit muscle aldolase $\left(M_{\mathrm{r}} 160000\right)$, rabbit muscle pyruvate kinase $\left(M_{\mathrm{r}} 232000\right)$ and horse apoferritin $\left(M_{\mathrm{r}} 440000\right)$.

Protein and peptide microsequencing. Protein and peptide samples for sequencing were resolved by SDS-PAGE in a separating gel appropriate for the $M_{\mathrm{r}}$ values of the samples, electroblotted onto PVDF membrane and subjected to microsequencing (Matsudaira, 1987) using an Applied Biosystems 477 A protein sequencer.

\section{Preparation of peptides from purified enzymes}

(a) S. coelicolor DAHP synthase. Purified enzyme was subjected to SDS-PAGE in a $10 \%(\mathrm{w} / \mathrm{v})$ gel. The bands were visualized by staining with Coomassie Blue R-250 for $5 \mathrm{~min}$, followed by destaining for $20 \mathrm{~min}$. The band corresponding to DAHP synthase was excised and neutralized in two changes of buffer containing $125 \mathrm{mM}$ Tris/ $\mathrm{HCl}(\mathrm{pH} 6 \cdot 8), 0 \cdot 1 \%$ SDS, $1 \mathrm{mM}$ DTT. The band was stored at $-20^{\circ} \mathrm{C}$ in the same buffer until ready to use. Gel slices were loaded onto a second $18 \%(\mathrm{w} / \mathrm{v})$ SDS gel, and the protein was digested with endoproteinase Glu-C (V8) during electrophoresis as described by Cleveland et al. (1977).

(b) S. rimosus and $N$. crassa DAHP synthases. Purified enzyme was digested with endoproteinase Lys-C. Digests were carried out under denaturing conditions at $37^{\circ} \mathrm{C}$ with a ratio of substrate to 
protease of 50:1 (w/w). The number and size of proteolytic fragments were analysed by SDS-PAGE throughout a timecourse of digestion and appropriate conditions to yield peptides capable of resolution by SDS-PAGE for subsequent electroblotting to PVDF membranes and microsequencing were determined.

Amino acid sequence comparison analysis. Amino acid sequences were analysed by using the sequence analysis programs of the University of Wisconsin Genetics Computer Group (Devereux et al., 1984).

\section{RESULTS AND DISCUSSION}

\section{Purification and characterization of the $S$. coelicolor DAHP synthase}

This paper reports the purification to homogeneity of a single tryptophan-sensitive DAHP synthase from $S$. coelicolor. The small-scale purification is summarized in Table 1. The purified preparation was shown to be essentially electrophoretically homogeneous under both denaturing (Fig. 1) and non-denaturing conditions (data not shown). The purification, as judged by the final specific activity of $8.3 \mathrm{U} \mathrm{mg}^{-1}$, was 2380 -fold with an $8 \%$ yield (Table 1 ). This final specific activity was of a similar order to other homogeneous, purified, microbial and plant DAHP synthases (Sugimoto \& Shiio, 1980; Nimmo \& Coggins, 1981a; Pinto et al., 1986; Paravicini et al., 1989; Ray \& Bauerle, 1991; Stuart \& Hunter, 1993). No evidence was found during the purification to indicate the presence of more than one isoenzyme of DAHP synthase in $S$. coelicolor.

The subunit $M_{\mathrm{r}}$ of the purified enzyme, determined electrophoretically under denaturing conditions, was $54000 \pm 2000$ (Fig. 1) and the native $M_{\mathrm{r}}$, as estimated by gel-permeation chromatography, was $107000 \pm 10000$. This indicates that the native enzyme is a dimer.

The kinetic studies were carried out on enzyme purified to the penultimate stage using the small-scale procedure. At this stage, the enzyme was relatively stable and free of contaminating blank rates. Duplicate initial velocity values were determined as a function of the concentration of one substrate at a fixed saturating level of the other substrate (for $\mathrm{PEP}=0.5 \mathrm{mM}$, for $\mathrm{E} 4 \mathrm{P}=1 \mathrm{mM}$ ) using the direct continuous assay. Mean apparent $K_{\mathrm{m}}$ values for

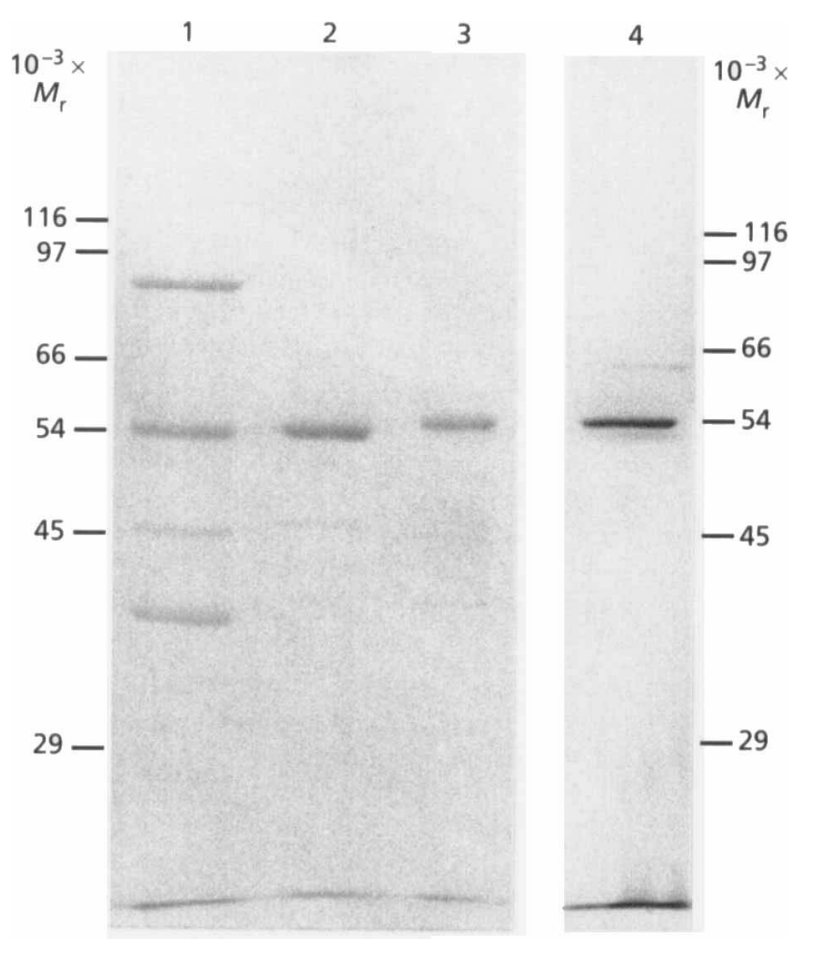

Fig. 1. Analysis of the purified S. coelicolor, S. rimosus and $N$. crassa DAHP synthases by SDS-PAGE. Tracks: 1, material from the final stage of the large-scale $S$. coelicolor DAHP synthase purification $(1.5 \mu \mathrm{g}) ; 2$, purified $S$. rimosus DAHP synthase $(0.5 \mu \mathrm{g}) ; 3$, purified $N$. crassa DAHP synthase $(0.5 \mu \mathrm{g}) ; 4, \mathrm{~S}$. coelicolor DAHP synthase (small-scale purification). Tracks 1-3 were run together and stained with Coomassie Brilliant Blue and track 4 was run on a separate gel and stained with silver nitrate. The positions of migration of $M_{r}$ markers are shown.

$\mathrm{E} 4 \mathrm{P}$ of $195 \pm 5 \mu \mathrm{M}$ and for PEP of $92 \pm 8 \mu \mathrm{M}$ were derived from direct linear plots using regression analysis (MultiFit software package). PEP acted as a normal Michaelis-Menten substrate, showing hyperbolic saturation, whereas $\mathrm{E} 4 \mathrm{P}$ acted as an inhibitor at concentrations above $1.1 \mathrm{mM}$, this inhibition being competitive with respect to PEP (data not shown).

A range of end-products and intermediates of the shikimate pathway were evaluated for their ability to

\section{Table 1. Small-scale purification of $S$. coelicolor DAHP synthase}

The results presented are for a typical purification starting from $70 \mathrm{~g}$ S. coelicolor cells.

\begin{tabular}{|lccccc|}
\hline Step & $\begin{array}{c}\text { Total } \\
\text { protein } \\
(\mathbf{m g})\end{array}$ & $\begin{array}{c}\text { Total } \\
\text { activity } \\
(\mathbf{m U})\end{array}$ & $\begin{array}{c}\text { Specific } \\
\text { activity } \\
\left(\mathbf{m U ~ m g}^{-1}\right)\end{array}$ & $\begin{array}{c}\text { Yield } \\
(\%)\end{array}$ & $\begin{array}{c}\text { Purification } \\
\text { (-fold) }\end{array}$ \\
\hline 1. Crude extract & 720 & 2520 & $3 \cdot 5$ & 100 & 1 \\
2. $\left(\mathrm{NH}_{4}\right)_{2} \mathrm{SO}_{4}$ fractionation & 288 & 1897 & $6 \cdot 6$ & 75 & $1 \cdot 9$ \\
3. Mono Q chromatography & 10 & 681 & $67 \cdot 3$ & 27 & 19 \\
4. Phenyl-Superose chromatography & $0 \cdot 22$ & 372 & 1690 & 15 & 483 \\
5. Mono Q chromatography & $0 \cdot 024$ & 200 & 8330 & 8 & 2380 \\
\hline
\end{tabular}




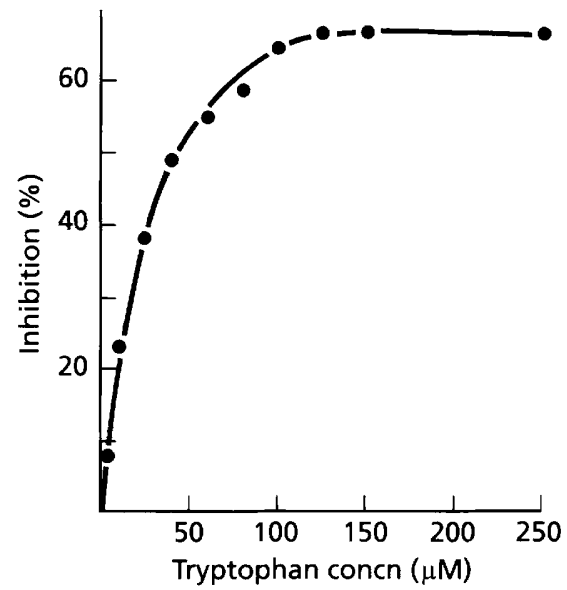

Fig. 2. Saturation curve of tryptophan inhibition of the $S$. coelicolor DAHP synthase. DAHP synthase was assayed by the direct method with the addition of between 0 and $250 \mu \mathrm{M}$ tryptophan to assays containing final concentrations of $50 \mu \mathrm{M}$ PEP and $100 \mu \mathrm{M}$ E4P.

inhibit DAHP synthase. Only tryptophan was found to show any significant effect. At concentrations up to $1 \mathrm{mM}$, tyrosine and phenylalanine had no effect on enzyme activity, and similarly at concentrations up to $0.25 \mathrm{mM}$, anthranilate and $p$-aminobenzoate gave no inhibition. The partial feedback inhibition by tryptophan was saturable with an apparent $K_{\mathrm{i}}$ of $70 \mu \mathrm{M}$ (Fig. 2).

The influence of $\mathrm{pH}$ upon enzyme activity was investigated. Partially purified enzyme was assayed directly in duplicate under saturating conditions at different $\mathrm{pH}$ intervals in bis-tris propane/ $\mathrm{HCl}$ buffer. Activity increased rapidly with increasing $\mathrm{pH}$ to an optimum between $\mathrm{pH} 7.0$ and $7 \cdot 4$; further increases in $\mathrm{pH}$ led to a strong decrease in activity.

Upon manipulation and storage, the activity was found to be extremely labile. Overnight dialysis, against buffer $B$ containing $10 \mathrm{mM}$ EDT A at $4{ }^{\circ} \mathrm{C}$, of aliquots redissolved from $\left(\mathrm{NH}_{4}\right)_{2} \mathrm{SO}_{4}$ pellets resulted in an $85 \%$ inactivation of the enzyme. Activity was also lost following overnight dialysis against Tris buffers at various $\mathrm{pH}$ values, possibly as a result of the metal-chelating properties of this buffer. Consequently, phosphate and bis-tris propane buffers were employed throughout the purification procedures and EDTA was omitted. It appears likely that this DAHP synthase requires a metal cofactor for activity, as described for other species (Stephens \& Bauerle, 1991). In the absence of a reductant, activity was lost, and $0.4 \mathrm{mM}$ DTT was included in all buffers. For the large-scale purification, one of the substrates (PEP) was included in all buffers. The polypeptide band responsible for the DAHP synthase activity was degraded upon storage. A co-purified lysine-specific protease was identified as being responsible following the sequencing of a band of $M_{\mathrm{r}} 54000$, the largest protein species corresponding to the DAHP synthase in the degraded material, which lacked the first five amino acids of the intact protein
(Table 3). The inclusion of PEP reduced the rate of proteolysis.

\section{Microsequencing and sequence comparisons of protein and peptides from the S. coelicolor DAHP synthase}

The specific activity of the material obtained by the largescale purification (Fig. 1, track 1) was $2.6 \mathrm{U} \mathrm{mg}^{-1}$, representing a 780 -fold purification with a $15 \%$ yield. This final protein sample comprised several polypeptide species (Fig. 1, track 1). DAHP synthase activity correlated with the band of $M_{\mathrm{r}} 54000$, matching the size of the species identified as DAHP synthase by the small-scale procedure. An aliquot of the pool was subjected to SDSPAGE and electroblotted to PVDF membrane. The Nterminal amino acid residues from positions 1 to 14 of the DAHP synthase were unambiguously assigned (Table 3 ). This material was also used to generate peptides from in situ proteolysis with V8 proteinase. Only one of the peptides $\left(M_{\mathrm{r}} 25000\right)$ generated yielded useful sequence. Twenty-one residues from this peptide were sequenced and found to match the $\mathrm{N}$-terminal sequence (Table 3 ).

This sequence did not show a significant match to DAHP synthase sequences in the databases, nor to any sequence lodged on the database. This was not unexpected as the first 41 residues of the otherwise highly homologous $E$. coli isoenzymes share only six amino acid identities (Ray et al., 1988); similarly, the protein sequences deduced from plant cDNA clones are largely identical, except, again, in their N-terminal portions, which appear characteristic of chloroplast transit sequences (Dyer et al., 1990; Keith et al., 1991).

There are many other examples of proteins, otherwise highly conserved, displaying heterogeneity in amino acid sequence at their $\mathrm{N}$-termini. Furthermore, it is difficult to assess the significance of amino acid alignments over short regions (e.g. 10-20 residues) and the probability of a match occurring by chance can be significant (Doolittle, 1981). In conclusion, these $\mathrm{N}$-terminal amino acid sequence data alone cannot be used for the analysis of the relatedness of DAHP synthase species, and further internal peptide sequence information is required.

\section{Purification and characterization of the S. rimosus DAHP synthase}

A purification to apparent homogeneity of the tryptophan-sensitive DAHP synthase from $S$. rimosus was reported during the course of this work (Stuart \& Hunter, 1993). With the instability of the $S$. coelicolor DAHP synthase activity rendering attempts to obtain internal amino acid sequence from purified enzyme technically difficult, the probability of obtaining reasonable amounts of enzyme from which to obtain internal amino acid sequence for DAHP synthase seemed greater using $S$. rimosus as a source of Streptomyces enzyme.

The enzyme was prepared in a novel six-step procedure yielding several hundred micrograms of material (Table 
Table 2. Purification of S. rimosus DAHP synthase

The results presented are for a typical purification starting from $85 \mathrm{~g}$ S. rimosus cells.

\begin{tabular}{|c|c|c|c|c|c|}
\hline Step & $\begin{array}{c}\text { Total } \\
\text { protein } \\
(\mathrm{mg})\end{array}$ & $\begin{array}{c}\text { Total } \\
\text { activity } \\
\text { (mU) }\end{array}$ & $\begin{array}{c}\text { Specific } \\
\text { activity } \\
\left(\mathrm{mU} \mathrm{mg}^{-1}\right)\end{array}$ & $\begin{array}{c}\text { Yield } \\
(\%)\end{array}$ & $\begin{array}{c}\text { Purification } \\
\text { (-fold) }\end{array}$ \\
\hline 1. Crude extract & 3300 & 9705 & $2: 9$ & 100 & 1 \\
\hline 2. $\left(\mathrm{NH}_{4}\right)_{2} \mathrm{SO}_{4}$ fractionation & 1512 & 13456 & 8.9 & 139 & $3 \cdot 1$ \\
\hline 3. DEAE-Sephacel chromatography & 74 & 6664 & 90 & 69 & 31 \\
\hline 4. Phenyl-Sepharose chromatography & $8 \cdot 8$ & 5932 & 674 & 61 & 229 \\
\hline 5. Mono Q chromatography & 0.96 & 4000 & 5422 & 41 & 1844 \\
\hline 6. Phenyl-Superose chromatography & $0 \cdot 175$ & 1928 & 11020 & 20 & 3750 \\
\hline
\end{tabular}

2). The purified preparation was shown to be essentially homogeneous by electrophoresis under denaturing conditions (Fig. 1). The purification, as judged by the final specific activity of $11.02 \mathrm{U} \mathrm{mg}^{-1}$, was 3750 -fold with a $20 \%$ yield (Table 2 ). This final specific activity was $40 \%$ higher than that of $7.83 \mathrm{U} \mathrm{mg}^{-1}$ reported previously (Stuart \& Hunter, 1993). The subunit $M_{\mathrm{r}}$ was estimated to be 54000 , similar to that obtained for the $S$. coelicolor DAHP synthase (54000: this study), the tryptophansensitive $N$. crassa DAHP synthase (52000: Nimmo \& Coggins, 1981a; 54000: this study) and the mature plastidic potato DAHP synthase (53000: Dyer et al., 1990). The previous subunit $M_{\mathrm{r}}$ value of 59000 (Stuart \& Hunter, 1993) appears to be an overestimate.

This activity was found to be remarkably stable in comparison with the S. coelicolor enzyme. The inclusion of anti-protease agents was unnecessary and the addition of PEP in buffers did not improve the yield of enzyme activity.

\section{Microsequencing and sequence comparisons of peptides from the $S$. rimosus DAHP synthase}

An aliquot of the final pool was subjected to N-terminal amino acid sequence analysis following electrophoresis and electroblotting onto PVDF membrane. No sequence was obtained and it was concluded that the $\mathrm{N}$-terminus was blocked. This material was also used to generate peptides following proteolysis with endoproteinase LysC. Many of the peptides did not yield sequence and were presumed to include the blocked $\mathrm{N}$-terminus. Only one of the isolated peptides $\left(M_{\mathrm{r}} 10000\right)$ yielded useful sequence (Table 3). This sequence showed similarity to the plant DAHP synthases, with a sequence identity of $58 \%$ in a 19 amino acid overlap (Fig. 3). It appears likely that this peptide corresponds to the C-terminal region of the $S$. rimosus DAHP synthase. Translation of the plant nucleotide sequences from this region of alignment to the stop codons also results in peptide sequences of around $M_{\mathrm{r}} 10000$. The peptide sequence was unrelated to any other previously published microbial DAHP synthase sequence.

Another sequence similar to the $S$. rimosus $M_{\mathrm{r}} 10000$ peptide sequence was found in the database. The over- lapping 19 amino acid sequence was found to match completely part of an amino acid sequence translated from a Streptomyces lividans nucleotide sequence (Fig. 3). The authors had submitted this DNA sequence to the database as part of a region of DNA which contained the sequence of a secretory signal peptide (L. L. Liaw and others; accession number L13767). The region upstream of the sequence encoding this secretory signal peptide appears to encode the C-terminal 146 amino acids of $S$. lividans DAHP synthase. The $S$. lividans sequence displayed the highest sequence identity with the potato (StshkB) and the $A$. thaliana 1 DAHP synthases $(53 \%$ and $52 \%$, respectively, of amino acid residues identical). It remains to be established whether the entire $S$. lividans gene corresponding to this partial nucleotide sequence encodes a functional DAHP synthase.

\section{Microsequencing and sequence comparisons of peptides from the $N$. crassa DAHP synthase}

$N$. crassa possesses three isoenzymes of DAHP synthase, each of which is subject to feedback inhibition by one of the three aromatic amino acids (Jensen \& Nasser, 1968; Hoffmann et al., 1972). Of these, only the tryptophansensitive isoenzyme has been purified to homogeneity and extensively characterized (Nimmo \& Coggins, 1981a, b). We believed that it would be of interest and relevance to our studies of the DAHP synthases of Streptomyces to obtain amino acid sequence information from the $N$. crassa enzyme, as it shares with the Streptomyces enzymes the features of large subunit size and sensitivity to tryptophan.

The purification yielded enzyme with a final specific activity of $7 \cdot 7 \mathrm{U} \mathrm{mg}^{-1}$, representing a 2000 -fold enrichment on the starting material. The purified preparation was shown to be essentially homogeneous by electrophoresis under denaturing conditions (Fig. 1) and the subunit $M_{\mathbf{r}}$ was estimated to be $54000 \pm 2000$.

An aliquot of the final pool was subjected to $\mathrm{N}$-terminal amino acid sequence analysis following electrophoresis and electroblotting onto PVDF membrane. No sequence was obtained and it was concluded that the $\mathrm{N}$-terminus was blocked. This material was then used to generate peptides using endoproteinase Lys-C. Several peptides 


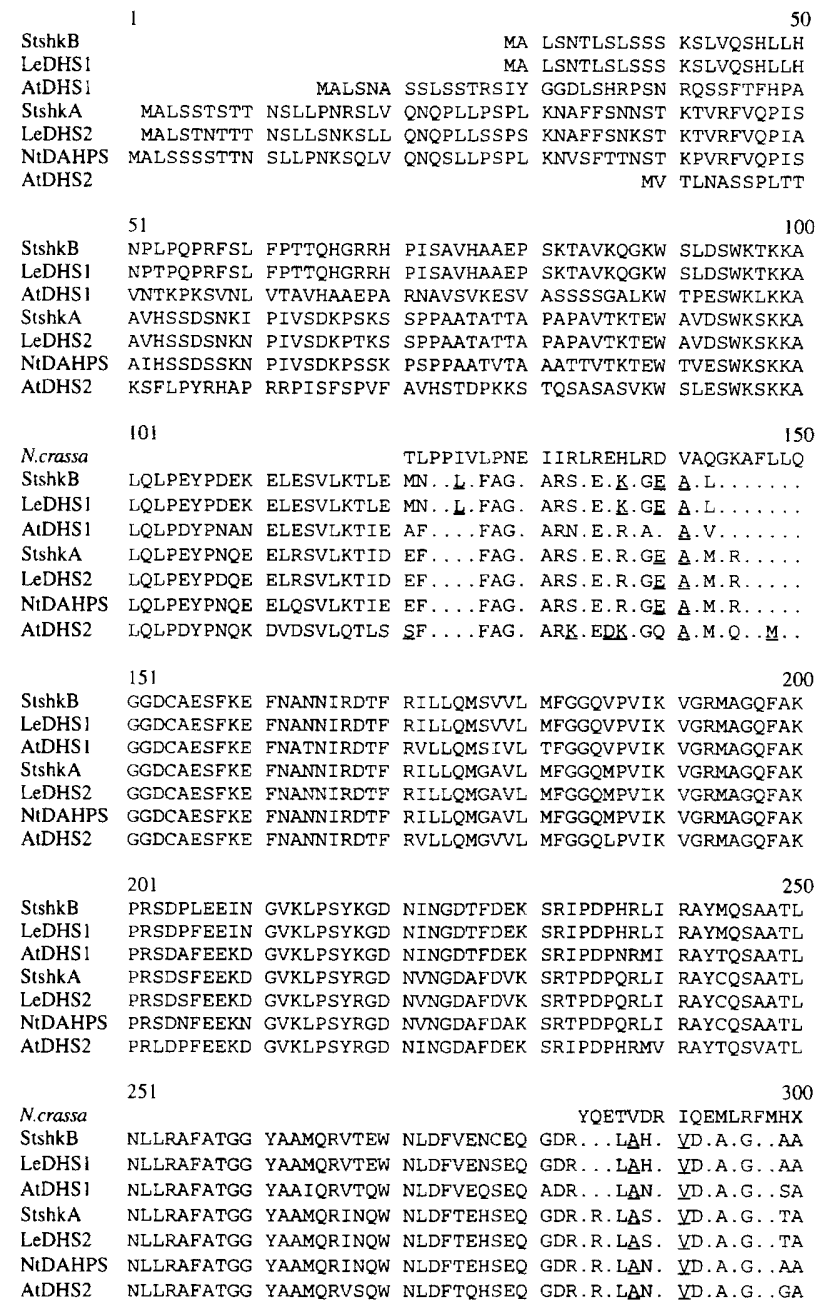
(1) AQGKAFLLQ LQLPEYPDEK ELESVLKTLE MLN.L.FAG. ARS.E. K.GE A.L. .

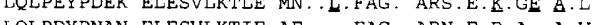
FF. . FAG. ARS. B.R.G. A.M. . . . LQLPEYPDQE ELRSVLKTID EF . . FAG. ARS.E.R.GE A.M.R . . LQLPDYPNQK DVDSVLQTLS SF ...FAG. ARK.EDK.GQ A.M.Q..M. 200

(1)

\begin{tabular}{|c|c|c|c|c|}
\hline & 301 & & & 350 \\
\hline N.crassa & IGADQNEK L STVELFTSHE & GLLLEYEEPL & TTXLNAPSQ & \\
\hline SishkB & A. LTVDHPIM . TDFW . . & C...P.QA. & REDSTSGLF & YDCSAHMVWV \\
\hline LeDHS 1 & A. LTVDHPIM & . P. .QA. & . REDSTSGLF & YDCSAHMVWV \\
\hline AtDHS 1 & C. LGTDHPLM T.TDFY. & C...P.QS. & . RLDSTSGLY & YDCSAHMVWC \\
\hline StshkA & A. LTMDHPIM K.T.FW . . & C...P. QS. & . RRDSTSGLY & YDCSAHFLWV \\
\hline LeDHS2 & A. LTMDHPIM K.T. FW. & . P. QQS. & . RRDSTSGLH & YDCSAHFLWV \\
\hline NEDAHPS & A. LTVDHPIM K.T.FW. & C...P. QS . & . RLDSTSGLY & YDCSAHFIWV \\
\hline AlDHS2 & A.LTSAHPIM T.T.FW . . & C..P.QA. & REDSTSGLY & YDCSAHMLWV \\
\hline
\end{tabular}
AIDHS2 A.LTSAHPIM I.T.FW.... C...P. . QA. .REDSTSGLY YDCSAHMLWV

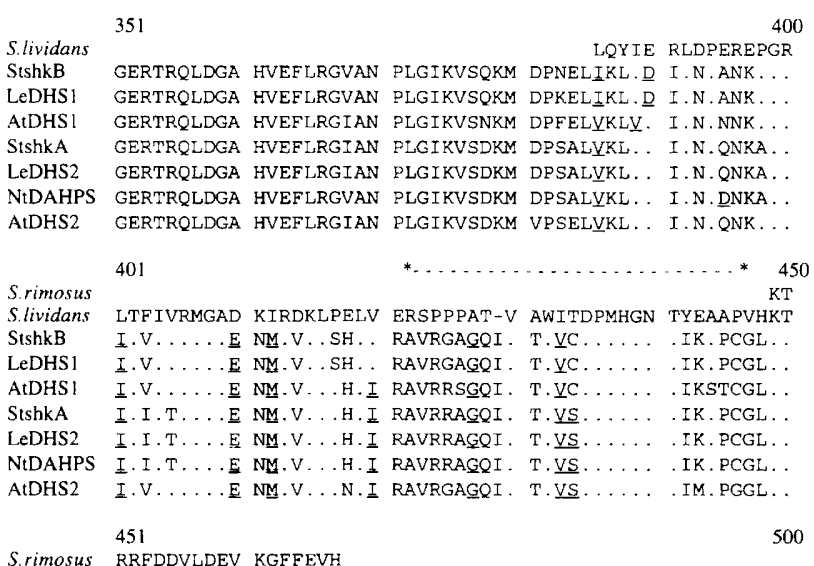

$\begin{array}{ll}\text { S.rimosus } & \text { RRFDDVLDEV KGFFEVH } \\ \text { S.lividans } & \text { RRFDDVLDEV KGFFEVHKSL GTHPGGIHVE LTGDDVTECV GGGDEIFVDD }\end{array}$

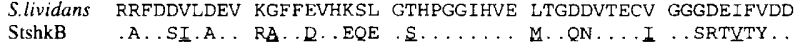

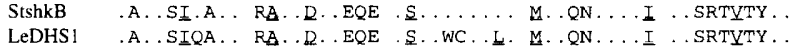

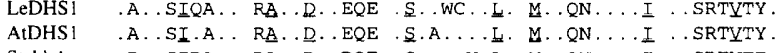

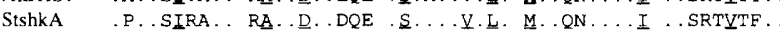

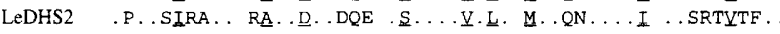

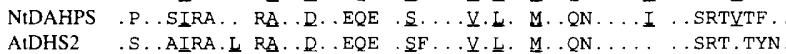

S.lividans LHQRYETACD PRLNRSQSLD LAFLVAEMYR DQ

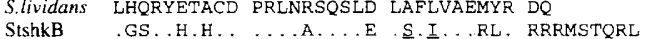

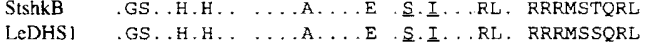

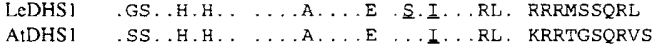

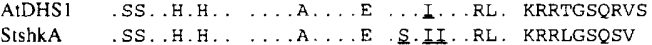

LEDHS2 IS..H.H. . . . A A...E S.II.RL. KRRLGSQSTL GQ

NtDAHPS .SS .H.H. ...A...E ..II..RL. KRRLGSQNVL GQ

ALDHS2 .SS..H.H. . ...A...E ...II.RL. KRRLGSGNLP SSIGV

Fig. 3. Multiple alignment of the $S$. rimosus, the $N$. crassa and the putative $S$. lividans DAHP synthase sequences with those of plants. The alignment of the $S$. rimosus peptide sequence, the three $N$. crassa peptide sequences and the $S$. lividans DNA sequence encoding part of a putative DAHP synthase with the plant DAHP synthase sequences is shown. All sequences are shown by the single letter amino acid code. The S. lividans sequence was determined by L. L. Liaw and others (accession number L13767); the alignment has been improved by allowing for two frameshifts, at the asterisked positions, which are required to keep the reading frame open. The Arabidopsis sequences (AtDHS1, AtDHS2) have been taken from Keith et al. (1991), the potato sequences (StshkA, StshkB) from Dyer et al. (1990) and Zhao \& Herrmann (1992), the tobacco sequence (NtDAHPS) from Wang et al. (1991) and the tomato sequences (LeDHS1, LeDHS2) from Gorlach et al. (1993). The correct endoproteinase Lys-C cleavage site is assumed to be present on the S. rimosus enzyme. Dots represent identity with the $N$. crassa or $S$. lividans sequences and conservative amino acid substitutions are underlined. The letter $X$ represents amino acid residues unidentified during the microsequencing. A dash indicates a gap introduced to improve the alignment.

failed to sequence and were presumed to contain the blocked $\mathrm{N}$-terminus. Four peptides yielded sequence; two of these had identical N-terminal amino acid sequences and must be overlapping partial digest products. Altogether 83 residues were obtained from the three nonoverlapping peptides (Table 3). The sequences showed similarity to the plant DAHP synthases (Fig. 3). These peptide sequences were unlike any other previously published microbial DAHP synthase sequences.

For the peptide of $M_{\mathrm{r}} 19000$ (Table 3), the highest degree of identity was found with the Arabidopsis (AtDHS1) DAHP synthase in a 30 amino acid overlap ( $57 \%$ identity of amino acid residues). For the peptide of $M_{\mathrm{r}} 18000$
(Table 3), the highest degree of identity was found with the Arabidopsis (AtDHS1), tomato (LeDHS1) and potato (StshkB) DAHP synthases in a 25 amino acid overlap ( $52 \%$ identity of amino acid residues). Finally, the peptide of $M_{\mathrm{r}} 13000$ ('Table 3) exhibited the highest sequence identity with the tomato (LeDHS1) and potato (StshkB) DAHP synthases in a 30 amino acid overlap (43\% identity of amino acid residues).

\section{Implications for the classification and evolutionary history of DAHP synthase enzymes}

The sequences of the microbial DAHP synthases obtained before the work reported here exhibit a striking level of 
Table 3. Amino acid sequences obtained from microsequence analysis

\begin{tabular}{|lll|}
\hline Organism & \multicolumn{1}{c|}{ Sample } & \multicolumn{1}{c|}{ Sequence* } \\
\hline S. coelicolor & Intact protein & TVNAKTSPSAGNTD \\
& $25000 M_{\mathrm{r}}$ peptide & TVNAKTSPSAGNTDDPLQAPS \\
S. rimosus & $10000 \mathrm{M}_{\mathrm{r}}$ peptide & TRRFDDVLDEVKGFFEVH \\
N. crassa & $19000 \mathrm{M}_{\mathrm{r}}$ peptide & TLPPIVLPNEIRLREHLRDVAQGKAFLLQ \\
& $18000 \mathrm{M}_{\mathrm{r}}$ peptide & YQETVDRIQEMLRFMHPIGADQNEK \\
& $13000 \mathrm{M}_{\mathrm{r}}$ peptide & LSTVELFTSHEGLLLEYEEPLTT?LNAPSQ \\
\hline
\end{tabular}

* Unidentified amino acids are indicated by '??

sequence similarity, suggesting that they are derived from a common ancestral sequence (Pittard, 1987; Ray et al., 1988; Kunzler et al., 1992; Chen et al., 1993; Pereira \& Livi, 1993). The DAHP synthase sequences identified in plants similarly display a high degree of similarity but are unrelated to the microbial sequences (Dyer et al., 1990; Keith et al., 1991; Gorlach et al., 1993). This information leads to the conclusion that two distinct classes of DAHP synthase have evolved. We define a type I DAHP synthase as having an $E$. coli-like sequence with a monofunctional subunit $M_{\mathrm{r}}$ of around 39000 and a type II DAHP synthase as having a plant-like sequence with a monofunctional subunit $M_{\mathrm{r}}$ of around 54000 (disregarding the chloroplast-targeting region). Our sequence data for the Streptomyces and Neurospora enzymes indicate that type II DAHP synthases also occur in prokaryotic and eukaryotic microbial species.

This situation is not unprecedented in the shikimate pathway. The third step of the pathway is catalysed by the dehydroquinases, which also fall into two distinct classes, type I and type II (Giles et al., 1985; White et al., 1990; Garbe et al., 1991; Euverink et al., 1992; Kleanthous et al., 1992; Hawkins et al., 1993), distinguished by their nonhomologous amino acid sequences (Charles et al., 1985; Da Silva et al., 1986; Duncan et al., 1987) and by kinetic, mechanistic, structural and biophysical criteria (Kleanthous et al., 1992; Harris et al., 1993; Gourley et al., 1994).

Variations of the shikimate pathway may exist. Enzymes have been postulated to be capable of catalysing analogous reactions to the orthodox pathway with modified substrates such as amino-DAHP (Kim et al., 1992). Such a modified shikimate pathway may exist in organisms such as Nocardia and Streptomyces which require the shikimatepathway-derived precursor 3-amino-5-hydroxybenzoic acid for ansamycin biosynthesis (Kim et al., 1992). These variant pathways may utilize the same shikimate pathway enzymes to synthesize 3-amino-5-hydroxybenzoic acid or they may employ other enzymes. If single enzyme activities fulfil both roles in an individual organism, then some degree of substrate ambiguity would be necessary. It is possible that this requirement for ambiguous substrate specificity may provide an explanation for the presence of a plant-like DAHP synthase in some micro-organisms and not in others.
Prior to this study, no amino acid sequence information was available from any microbial source which indicated that the DAHP synthases from some bacteria and fungi were related to those of plants. Our data establish that plant-like type II DAHP synthases exist in different bacteria and fungi. The sequence conservation between the type II DAHP synthases from such evolutionary distant organisms as Streptomyces and plants should assist with the identification of functionally important residues and regions in the enzymes.

\section{ACKNOWLEDGEMENTS}

We thank Mr John Greene for technical assistance and $\mathrm{Mr}$ Malcolm Horsburgh for help with computer sequence analysis. A major part of this work was supported by the SERC Initiative, Secondary Metabolism of Streptomyces, involving Glaxo and SmithKline Beecham.

\section{REFERENCES}

Bentley, R. (1990). The shikimate pathway - a metabolic tree with many branches. Crit Rev Biochem Mol Biol 25, 307-384.

Bradford, M. M. (1976). A rapid and sensitive method for the quantitation of microgram quantities of protein utilizing the principle of protein-dye binding. Anal Biochem 72, 248-254.

Bramwell, H., Nimmo, H. G., Hunter, I. S. \& Coggins, J. R. (1993). Phosphoenolpyruvate carboxylase from Streptomyces coelicolor $\mathrm{A} 3(2)$; purification of the enzyme, cloning of the $p p c$ gene and overexpression of the protein in a streptomycete. Biocbem J 293, 131-136.

Charles, I. G., Keyte, J. W., Brammar, W. J. \& Hawkins, A. R. (1985). Nucleotide sequence encoding the biosynthetic dehydroquinase function of the pentafunctional $A R O M$ locus of Aspergillus nidulans. Nucleic Acids Res 13, 8119-8128.

Chater, K. F. \& Hopwood, D. A. (1993). Streptomyces. In Bacillus subtilis and other Gram-positive Bacteria: Biochemistry, Pbysiology, and Molecular Genetics, pp. 83-99. Edited by A. L. Sonenshein, J. Koch \& R. L. Losick. Washington, DC: American Society for Microbiology.

Chaudhuri, C., Anton, I. A. \& Coggins, J. R. (1987a). Shikimate dehydrogenase from Escherichia coli. Methods Envymol 142, 315-320.

Chaudhuri, C., Duncan, K. \& Coggins, J. R. (1987b). 3-Dehydroquinate dehydratase from Eschericbia coli. Methods Enzymol 142, 320-324. 
Chen, C. C., Liao, C. C. \& Hsu, W. H. (1993). The cloning and nucleotide sequence of a Corynebacterium glutamicum 3-deoxy-Darabino-heptulosonate-7-phosphate synthase gene. FEMS Microbiol Lett 107, 223-230.

Cleveland, D. W., Fischer, S. G., Kirschner, M. W. \& Laemmli, U. K. (1977). Peptide mapping by limited proteolysis in sodium dodecyl sulfate and analysis by gel electrophoresis. I Biol Chem 252, 1102-1106.

Coggins, J. R., Boocock, M. R., Chaudhuri, S., Lambert, J. M., Lumsden, J., Nimmo, G. A. \& Smith, D. D. S. (1987). The arom multifunctional enzyme in Neurospora crassa. Methods Enzymol 142 325-341

Da Silva, A. J. F., Whittington, H. W., Clements, J., Roberts, C. F. \& Hawkins, A. R. (1986). Sequence analysis and transformation by catabolic 3-dehydroquinase (QUTE) gene from Aspergillus nidulans. Biochem J 240, 481-488.

Davies, W. D. \& Davidson, B. E. (1982). The nucleotide sequence of aro $G$, the gene for 3-deoxy-D-arabino-heptulosonate-7-phosphate synthetase (phe) in Escbericbia coli K-12. Nucleic Acids Res 10, 4045-4058.

Demain, A. L. (1983). New applications of microbial products. Science 219, 709-714.

Devereux, J., Haeberli, P. \& Smithies, O. (1984). A comprehensive set of sequence analysis programs for the VAX. Nucleic Acids Res 12, 387-395.

Doolittle, R. F. (1981). Similar amino acid sequences: chance or common ancestry. Science 214, 149-159.

Duncan, K., Edwards, R. M. \& Coggins, J. R. (1987). The pentafunctional arom enzyme of Saccharomyces cerevisiae is a mosaic of monofunctional domains. Biochem J 246, 375-386.

Dyer, W. E., Weaver, L. M., Zhao, J., Kuhn, D. N., Weller, S. C. \& Herrmann, K. M. (1990). A cDNA encoding 3-deoxy-D-arabinoheptulosonate-7-phosphate synthase from Solanum tuberosum L.J Biol Chem 265, 1608-1614.

Euverink, G. J. W., Hessels, G. I., Vrijbloed, J. W., Coggins, J. R. \& Dijkhuizen, L. (1992). Purification and characterization of a dual function 3-dehydroquinate dehydratase from Amycolatopsis methanolica. J Gen Microbiol 138, 2449-2457.

Garbe, T., Servos, S., Hawkins, A. R., Dimitriadis, G., Young, D., Dougan, G. I. \& Charles, I. G. (1991). The Mycobacterium tuberculosis shikimate pathway genes: evolutionary relationships between biosynthetic and catabolic 3-dehydroquinases. Mol Gen Genet 228, 385-392.

Giles, N. H., Case, M. E., Baum, J., Geever, R., Huiet, L., Patel, V. \& Tyler, B. (1985). Gene organisation and regulation in the QA (quinic acid) cluster of Neurospora crassa. Microbiol Rev 49, 338-358.

Gorlach, J., Beck, A., Henstrand, J. M., Handa, A. V., Herrmann, K. M., Schmid, J. \& Amrhein, N. (1993). Differential expression of tomato (Lycopersicon esculentum L.) genes encoding shikimate pathway isoenzymes. I. 3-Deoxy-D-arabino-heptulosonate-7-phosphate synthase. Plant Mol Biol 23, 697-706.

Gourley, D. G., Coggins, J. R., Isaacs, N. W., Moore, J. D., Charles, I. G. \& Hawkins, A. R. (1994). Crystallization of a type II dehydroquinase from Mycobacterium tuberculosis. J Mol Biol 241, 488-491.

Harris, J., Kleanthous, C., Coggins, J. R., Hawkins, A. R. \& Abell, C. (1993). Different mechanistic and stereochemical course for the reactions catalysed by type I and type II dehydroquinases. $J$ Chem Soc Chem Commun 1080-1081.

Haslam, E. (1974). The Shikimate Pathway. London: Butterworths. Haslam, E. (1993). Sbikimic Acid: Metabolism and Metabolites. Chichester: Wiley and Sons.
Hawkins, A. R., Lamb, H. K., Moore, J. D., Charles, I. G. \& Roberts, C. F. (1993). The pre-chorismate (shikimate) and quinate pathways in filamentous fungi: theoretical and practical aspects. $J$ Gen Microbiol 139, 2891-2899.

Herrmann, K. M. (1983). The common aromatic biosynthetic pathway. In Amino Acids: Biosynthesis and Genetic Regulation, pp. 301-322. Edited by K. M. Herrmann \& R. L. Somerville. Reading, MA: Addison-Wesley Publishing.

Hoffmann, P. J., Doy, C. H. \& Catcheside, D. E. A. (1972). The separation of the three allosterically inhibited 3-deoxy-D-arabinoheptulosonate-7-phosphate synthases from extracts of Neurospora crassa and the purification of the tyrosine inhibitable isoenzyme. Biochim Biophys Acta 268, 550-561.

Jensen, R. A. \& Nasser, D. S. (1968). Comparative regulation of isoenzymic 3-deoxy-D-arabino-heptulosonate-7-phosphate synthetases in microorganisms. J Bacteriol 95, 1582-1593.

Keith, B., Dong, X., Ausubel, F. M. \& Fink, G. R. (1991). Differential induction of 3-deoxy-D-arabino-heptulosonate-7-phosphate synthase genes in Arabidopsis thaliana by wounding and pathogenic attack. Proc Natl Acad Sci USA 88, 8821-8825.

Kim, C. G., Kirschning, A., Bergon, P., Ahn, Y., Wang, J. J., Shibuya, M. \& Floss, H. G. (1992). Formation of 3-amino-5hydroxybenzoic acid, the precursor of $\mathrm{mC} 7 \mathrm{~N}$ units in ansamycin antibiotics, by a new variant of the shikimate pathway. J Am Chem Soc 114, 4941-4943.

Kleanthous, C., Deka, R., Davis, K., Kelly, S. M., Cooper, A., Harding, S. E., Price, N. C., Hawkins, A. R. \& Coggins, J. R. (1992). A comparison of the enzymological and biophysical properties of two distinct classes of dehydroquinase enzymes. Biochem J 282, 687-695.

Kunzler, M., Paravicini, G., Egli, C. M., Irniger, S. \& Braus, G. H. (1992). Cloning, primary structure and regulation of the $A R O 4$ gene, encoding the tyrosine-inhibited 3-deoxy-D-arabinoheptulosonate-7-phosphate synthase of Saccbaromyces cerevisiae. Gene $113,67-74$

Laemmli, U. K. (1970). Cleavage of structural proteins during the assembly of the head of bacteriophage T4. Nature 227, 680-685.

Lumsden, J. \& Coggins, J. R. (1977). The subunit structure of the arom multienzyme complex of Neurospora crassa. A possible pentafunctional polypeptide chain. Biochem J 161, 599-607.

Matsudaira, P. (1987). Sequence from picomole quantities of proteins electroblotted onto polyvinylidene difluoride membranes. J Biol Chem 262, 10035-10038.

Mehdi, S., Frost, J. W. \& Knowles, J. R. (1987). Dehydroquinate synthase from Escherichia coli, and its substrate 3-deoxy-D-arabinoheptulosonate acid 7-phosphate. Methods Enzymol 142, 306-314.

Mousdale, D. M. \& Coggins, J. R. (1993). The shikimate pathway. Methods Plant Biochem 9, 1-23.

Muday, G. K. \& Herrmann, K. M. (1990). Regulation of the Salmonella typhimurium aroF gene in Eschericbia coli. J Bacteriol 172, 2259-2266.

Nimmo, G. A. \& Coggins, J. R. (1981a). The purification and molecular properties of the tryptophan-sensitive 3-deoxy-D-arabinoheptulosonate-7-phosphate synthase from Neurospora crassa. Biocbem $J$ 197, 427-436.

Nimmo, G. A. \& Coggins, J. R. (1981b). Some kinetic properties of the tryptophan-sensitive 3-deoxy-D-arabino-heptulosonate-7-phosphate synthase from Neurospora crassa. Biocbem J 199, 657-665.

Paravicini, G., Braus, G. \& Hutter, R. (1988). Structure of the $A$ RO 3 gene of Saccharomyces cerevisiae. Mol Gen Genet 214, 165-169.

Paravicini, G., Schmidheini, T. \& Braus, G. (1989). Purification and properties of the 3-deoxy-D-arabino-heptulosonate-7-phosphate syn- 
thase (phenylalanine-inhibitable) of Saccharomyces cerevisiae. Eur J Biochem 186, 361-366.

Pereira, S. A. \& Livi, G. P. (1993). Cloning and expression of the ARO3 gene encoding DAHP synthase from Candida albicans. Gene 132, $159-165$.

Pinto, J. E. B., Suzich, J. A. \& Herrmann, K. M. (1986). 3-Deoxy-Darabino-heptulosonate-7-phosphate synthase from potato tuber (Solanum tuberosum L.). Plant Physiol 82, 1040-1044.

Pittard, A. J. (1987). Biosynthesis of the aromatic amino acids. In Escherichia coli and Salmonella typhimurium: Cellular and Molecular Biology, pp. 368-394. Edited by F. C. Neidhardt, J. L. Ingraham, K. Brooks Low, B. Magasanik, M. Schaechter \& H. E. Umbarger. Washington, DC: American Society for Microbiology.

Ray, J. M. \& Bauerle, R. (1991). Purification and properties of tryptophan-sensitive 3-deoxy-D-arabino-heptulosonate-7-phosphate synthase from Eschericbia coli. J Bacteriol 173, 1894-1901.

Ray, J. M., Yanofsky, C. \& Bauerle, R. (1988). Mutational analysis of the catalytic and feedback sites of the tryptophan-sensitive 3deoxy-D-arabino-heptulosonate-7-phosphate synthase of Eschericbia coli. J Bacteriol 170, 5500-5506.

Schoner, R. \& Herrmann, K. M. (1976). 3-Deoxy-D-arabinoheptulosonate 7-phosphate synthase: purification, properties and kinetics of the tyrosine-sensitive isoenzyme of Escherichia coli. J Biol Chem 251, 5440-5447.

Schultz, J., Hermondson, M. A., Garner, C. C. \& Hermann, K. M. (1984). The nucleotide sequence of the aroF gene of Escherichia coli and the amino acid sequence of the encoded protein, the tyrosinesensitive 3-deoxy-D-arabino-heptulosonate-7-phosphate synthase. $J$ Biol Chem 259, 9655-9661.

Srinivasan, P. R. \& Sprinson, D. B. (1959). 2-Keto-3-deoxy-Darabino-heptonic acid 7-phosphate synthetase. J Biol Chem 234, 716-722.
Stephens, C. M. \& Bauerle, R. (1991). Analysis of the metal requirement of 3-deoxy-D-arabino-heptulosonate-7-phosphate synthase from Eschericbia coli. J Biol Chem 266, 20810-20817.

Stuart, F. \& Hunter, I. S. (1993). Purification and characterisation of 3-deoxy-D-arabino-heptulosonate-7-phosphate synthase from Streptomyces rimosus. Biochim Biopbys Acta 1161, 209-215.

Sugimoto, S. \& Shiio, I. (1980). Purification and properties of bifunctional 3-deoxy-D-arabino-heptulosonate-7-phosphate synthetase-chorismate mutase component A from Brevibacterium flavum. J Biochem 87, 881-890.

Wang, Y., Herrmann, K. M., Weller, S. C. \& Goldsbrough, P. B. (1991). Cloning and nucleotide sequence of a complementary DNA encoding 3-deoxy-D-arabino-heptulosonate-7-phosphate synthase from tobacco. Plant Pbysiol 97, 847-848.

Weiss, U. \& Edwards, J. M. (1980). The Biosynthesis of Aromatic Compounds. New York: Wiley-Interscience.

White, P. J., Young, J., Hunter, I. S., Nimmo, H. G. \& Coggins, J. R. (1990). The purification and characterisation of 3-dehydroquinase from Streptomyces coelicolor. Biochem J 265, 735-738.

Wray, W., Bonlikas, T., Wray, V. P. \& Hancock, R. (1981). Silver staining of proteins in polyacrylamide gels. Anal Biochem 118, 197-203.

Xia, T., Zhao, G. \& Jensen, R. A. (1993). The phe $A /$ tyr $A /$ aroF region from Erwinia berbicola: an emerging comparative basis for analysis of gene organization and regulation in enteric bacteria. $J$ Mol Evol 36, 107-120.

Zhao, J. \& Herrmann, K. M. (1992). Cloning and sequencing of a second cDNA encoding 3-deoxy-D-arabino-heptulosonate-7-phosphate synthase from Solanum tuberosum L. Plant Pbysiol 100, 1075-1076.

Received 1 March 1996; accepted 21 March 1996. 